\title{
The Role of Myeloid-Derived Suppressor Cells (MDSC) in Cancer Progression
}

\author{
Viktor Umansky ${ }^{1,2, *}$, Carolin Blattner ${ }^{1,2}$, Christoffer Gebhardt ${ }^{1,2}$ and Jochen Utikal ${ }^{1,2}$ \\ 1 Skin Cancer Unit, German Cancer Research Center (DKFZ), Heidelberg 69120, Germany; \\ c.blattner@dkfz.de (C.B.); c.gebhardt@dkfz.de (C.G.); j.utikal@dkfz.de (J.U.) \\ 2 Department of Dermatology, Venereology and Allergology, University Medical Center Mannheim, \\ Ruprecht-Karl University of Heidelberg, Mannheim 68167, Germany \\ * Correspondence: v.umansky@dkfz.de; Tel.: +49-621-383-3773; Fax: +49-621-383-2163 \\ Academic Editor: Theresa L. Whiteside \\ Received: 15 August 2016; Accepted: 31 October 2016; Published: 3 November 2016
}

\begin{abstract}
The immunosuppressive tumor microenvironment represents not only one of the key factors stimulating tumor progression but also a strong obstacle for efficient tumor immunotherapy. Immunosuppression was found to be associated with chronic inflammatory mediators including cytokines, chemokines and growth factors produced by cancer and stroma cells. Long-term intensive production of these factors induces the formation of myeloid-derived suppressor cells (MDSCs) representing one of the most important players mediating immunosuppression. Moreover, MDSCs could not only inhibit anti-tumor immune reactions but also directly stimulate tumor growth and metastasis. Therefore, understanding the mechanisms of their generation, expansion, recruitment and activation is required for the development of novel strategies for tumor immunotherapy.
\end{abstract}

Keywords: myeloid-derived suppressor cells; myelopoiesis; tumor microenvironment; immunosuppression; therapeutic targeting

\section{Introduction}

Myeloid-derived suppressor cells (MDSCs) represent a heterogeneous population of immature myeloid cells consisting of precursors for granulocytes, macrophages or dendritic cells (DCs) that are accumulated during chronic inflammation and tumor progression [1-4]. These cells show a broadly distinct phenotype. In mice, MDSCs express both CD11b and Gr1 markers and consist of two major subsets: polymorphonuclear Ly6G ${ }^{+}$Ly6 $6 C^{\text {lo }}(\mathrm{PMN})$ and monocytic Ly6G ${ }^{-}$Ly6 $6 \mathrm{C}^{\text {hi }}(\mathrm{M})$ cells $[1-3,5,6]$. In humans, the same two subsets can be characterized as $\mathrm{Lin}^{-} \mathrm{HLA}-\mathrm{DR}{ }^{-/ 10} \mathrm{CD} 33^{+}$ or $\mathrm{Lin}^{-} \mathrm{HLA}-\mathrm{DR}{ }^{-/ \mathrm{lo}} \mathrm{CD} 11 \mathrm{~b}^{+} \mathrm{CD} 14^{-} \mathrm{CD}_{15}{ }^{+} \mathrm{CD} 33^{+}$for PMN-MDSCs and CD $14^{+} \mathrm{HLA}-\mathrm{DR}{ }^{\text {neg }} / \mathrm{lo}$ or $\mathrm{Lin}^{-} \mathrm{HLA}-\mathrm{DR} \mathrm{n}^{\text {neg } / \mathrm{lo}} \mathrm{CD} 11 \mathrm{~b}^{+} \mathrm{CD} 14^{+} \mathrm{CD} 15^{-}$for M-MDSCs [1,2,7-9]. MDSCs derive from the bone marrow hematopoietic precursor cells through the pathologic modulation of myelopoiesis induced by constantly produced inflammatory mediators $[1-4,7]$ and exhibit remarkable immunosuppressive and tumorigenic activities [1-3,10]. These functions include (i) a deprivation of amino acids arginine and cysteine, which are essential for $\mathrm{T}$ cell proliferation and anti-tumor reactivity $[1,11,12]$; (ii) a production of nitric oxide (NO) and reactive oxygen species (ROS) that causes the nitration of $\mathrm{T}$ cell receptors (TCR) and chemokines important for $\mathrm{T}$ cell migration or inducing apoptosis of $\mathrm{T}$ cells and NK cells $[1-3,13,14]$; (iii) an intensive production of interleukin (IL)-10 and transforming growth factor (TGF)- $\beta 1$ inhibiting immune effector cell functions [1-3,11,15]; (iv) an upregulated expression of programmed death-ligand 1 (PD-L1) [1-3,16] which can drastically downregulate an anti-tumor T cell-mediated reactivity via interaction with PD-1 receptor expressed on T cells [17]; (v) a reduction of the TCR $\zeta$-chain expression playing an important role in coupling the TCR-mediated antigen recognition to diverse signal transduction pathways [4,18]; (vi) a secretion of angiogenic 
factors promoting tumor neovascularization $[19,20]$, and (vii) a production of growth factors, matrix metalloproteinases and cytokines stimulating tumor growth and skewing immune reactions towards Th2 type and activation of regulatory T cells (Tregs) [2,21,22]. Therefore, MDSCs can be considered as major players in tumor-mediated immunosuppression.

In this review, we will summarize current knowledge of the MDSC generation, migration and acquisition of strong immunosuppressive activity in the tumor microenvironment and will discuss possible targets that could be used for the neutralization of these cells.

\section{MDSCs Generation and Expansion during Tumor Progression}

Numerous reports published during the last decade described a strong correlation between the development of chronic inflammatory conditions in the tumor microenvironment and generation and expansion of MDSCs [1-4,18,23,24]. Furthermore, chronic inflammation has been found to be associated with the initiation and progression of various tumors [25]. Although the onset of some other tumors such as malignant melanoma is not generally associated with apparent inflammation, recent publications highlighted the critical importance of particular cytokines and chemokines for their fast progression [26]. Tumor cells are able to produce a variety of inflammatory mediators including granulocyte-macrophage colony-stimulating factor (GM-CSF), granulocyte colony-stimulating factor (G-CSF), macrophage colony-stimulating factor (M-CSF), stem cell factor (SCF), vascular endothelial growth factor (VEGF), TGF- $\beta$, tumor necrosis factor (TNF)- $\alpha$, IL-1 $\beta$, IL-6, and IL-10 [1-4,26,27]. The effect of all these factors is combinatorial and dose-dependent. Furthermore, tumor cells can induce the production of these factors by fibroblasts and immune cells in the tumor stroma [1,28]. Moreover, stromal cells can further stimulate the production of inflammatory mediators by tumor cells thereby creating autocrine and paracrine loops in the tumor progression [29]. Altogether, these inflammatory factors can modulate myeloid cells in the tumor microenvironment, and having them delivered distantly to hematopoietic organs can change normal myelopoiesis and skew the differentiation of myeloid cells in favor of MDSCs [2-4,10,23,30].

GM-CSF is considered as a major growth factor driving myelopoiesis [31,32], whereas further differentiation to granulocytes or macrophages is mediated by G-CSF or M-CSF, respectively [31]. These growth factors have been shown to be expressed in tumor lesions [18,23,27,33]. Tumor-derived GM-CSF has been demonstrated to play a major role in the generation of MDSCs both in vivo and in vitro [34,35]. Moreover, it has been reported that the effect of GM-CSF is dose-dependent: its low concentrations in the absence of IL-4 resulted in the generation of MDSCs and immature DCs from bone marrow hematopoietic precursors in vitro, whereas in high concentrations, it induced the development of neutrophils and mature DCs [36]. In addition, GM-CSF in combination with IL-6, IL-1 $\beta$, prostaglandin (PG) E2, TNF- $\alpha$ or VEGF has been reported to mediate the generation of highly suppressive MDSCs from $\mathrm{CD}_{3}{ }^{+}$peripheral blood mononuclear cells isolated from healthy donors [37]. Importantly, GM-CSF and IL-6 allowed a rapid and efficient generation of MDSCs with a strong tolerogenic activity from precursors present in mouse and human bone marrow [38].

VEGF and TGF- $\beta$ have also been demonstrated to be involved in the regulation of hematopoiesis $[39,40]$. Both growth factors are produced in high concentrations by many tumor types and display a strong impact on the MDSC generation and expansion [1-4,10,18]. It has been demonstrated that VEGF secreted by tumor cells interfered with the proliferation, differentiation and maturation of immature granulocyte-macrophage progenitors, causing an inhibition of DC maturation and activation as well as a development of immunosuppressive tumor-associated macrophages (TAMs) [41,42]. In combination with VEGF, TGF- $\beta$ prevented DC maturation, polarized myeloid cells towards immunosuppressive cells in the tumor microenvironment and participated in the induction of TAMs [43].

Impairment of normal myelopoiesis could be also induced by the alterations of cytokine production [44]. They are commonly present in the tumor microenvironment and are regulating by IL-1 $\beta[45,46]$. It has been documented that IL-1 $\beta$ accumulated at the tumor site is involved in the MDSC generation in bone marrow and in their migration towards tumor lesions [47,48]. Moreover, IL-1 $\beta$ was found to induce cyclooxygenase (COX)-2 expression $[46,49]$ that together with PGE2 could 
not only mediate an accumulation of MDSCs and TAMs and stimulate tumor progression but also prevent the maturation and activation of antigen presenting cells at the tumor site [50,51]. IL-1 $\beta$ was also demonstrated to up-regulate the production of TNF- $\alpha$ by myeloid and/or tumor cells in the tumor microenvironment [52] that significantly activates MDSC immunosuppressive functions [53,54]. In addition, IL-1 $\beta$ was reported to stimulate the IL-10 production by MDSCs and to play a role in the induction of IL-5 and IL-13 [3,11]. The latter cytokines could stimulate type 2 immune reactions and recruit MDSCs to the tumor microenvironment [55,56].

IL-6 is another cytokine that is critically important for MDSC generation and survival $[1,3,10,11]$. A strong link of this factor with chronic inflammation and cancer development has been demonstrated [57]. Increased IL-6 concentrations were shown to correlate with MDSC frequencies and their suppressive functions in tumor-bearing hosts [27,58]. The IL-6 signaling involves the signal transducer and activator of transcription 3 (STAT3), preventing MDSC differentiation and promoting their proliferation $[1,2,10,59,60]$. In addition, blocking IL-6 or IL-6R in prostate cancer and methylcholanthrene-induced skin squamous cell carcinoma mouse models resulted in the prominent reduction of MDSCs infiltrating tumors and in the suppression of tumor development [58,61].

Numerous publications have described a significant increase in the frequency of circulating M-MDSCs and PMN-MDSCs in patients with melanoma [7-9,62-66] and other tumor entities [7-9,67] that strongly correlated with tumor burden. Furthermore, circulating M-MDSCs have been reported to provide a negative impact on survival $[62,64,66]$ and inversely correlate with the presence of functional antigen-specific $\mathrm{T}$ cells in patients with advanced melanoma [64]. High frequencies of PMN-MDSCs correlate with poor prognosis in patients with breast or colorectal cancer $[68,69]$. The MDSC frequency in cancer patients increased during tumor development. However, 3-4 weeks after surgical resection of the tumor, the frequency of these cells decreased. These findings are consistent with the fact that the generation of MDSCs is due to the higher production of inflammatory factors secreted mostly by the tumor [70,71].

\section{MDSC Recruitment into the Tumor Site}

Chemokines are small (8-14 kDa), structurally related chemotactic cytokines that regulate trafficking of various cells (including leukocytes) through interactions with specific seven-transmembrane, $G$ protein-coupled receptors. Fifty endogenous chemokines that bind 20 receptors have been described [72]. Chemokines are considered to be key drivers in the development of inflammatory diseases and cancer [73]. The pattern of chemokines involved in MDSC migration into the tumor microenvironment seems to be dependent on the MDSC subset (monocytic or polymorphonuclear) and on the tumor model. The role of chemokine (C-C motif) ligand (CCL) 2 and its receptors in the attraction of M-MDSCs has been well described. In particular, it has been demonstrated that an accumulation of M-MDSCs in several mouse tumor models occurred via an interaction between CCL2 and its receptors, chemokine (C-C motif) receptor (CCR) 2, 4, and 5 [74,75]. Moreover, melanoma-infiltrating M-MDSCs displayed CCR2-dependent immunosuppressive activities in the presence of GM-CSF [74]. In the transplantable prostate cancer mouse model, it has been recently demonstrated that CCL2-CCR2 interaction plays a pivotal role in the recruitment of bone marrow-derived myeloid cells to the blood and their subsequent migration into the tumor site [76,77].

The production of CCL2 but also chemokine (C-X-C motif) ligand (CXCL) 8 (also known as IL-8), and CXCL12 can be induced by PGE2 resulting in a dramatic MDSC accumulation in the ovarian and gastric cancer microenvironment [78,79]. In contrast, the expression of CXCL12 has been found to reduce MDSC recruitment in breast cancer mouse model [80]. Other investigators reported a dominating role of CCL3, CCL5 and CX3CL1 but not CCL2 in the migration of M-MDSC [81] or an importance of CXCL-1 (also known as KC), CCL5 and CCL7 in the MDSC enrichment in mouse colon and liver carcinoma models [82,83]. Recently, it has been published that CCL5 strongly activated hypoxia-inducible factor (HIF)-1 $\alpha$ signaling cascades leading to the upregulation of VEGF expression [84]. Importantly, both HIF-1 $\alpha$ and VEGF are considered to play a key role in MDSC generation and functions $[16,85,86]$. Interestingly, comparing various transplantable tumor mouse 
models, Sawanobori et al. [87] observed that MDSC migration into the tumor site could be mediated by different chemokines.

Therefore, the migration of different MDSC subsets into the tumor site can be strongly determined by the histology and the spectrum of chemokines produced by particular tumors.

\section{MDSC Activation}

Numerous recent studies clearly demonstrated that after the generation and migration to the tumor site, MDSC significantly upregulated their immunosuppressive functions. This activating signal is provided by inflammatory molecules such as interferon (IFN)- $\gamma$, IL-1 $\beta$, IL-4, IL-13, TNF- $\alpha$, toll-like receptor (TLR) ligands, PGE2 and is mediated by transcription factors STAT1, STAT6 and nuclear factor (NF)- $\mathrm{kB}$ as well as by elevation of cyclooxygenase (COX)-2 activity $[1,2,11,18,23,24,53]$.

Notably, many of these inflammatory mediators (including IFN- $\gamma$, IL-1 $\beta$, IL-6, TNF- $\alpha$, CCL2, CCL3, CCL4, CCL5, etc.) are known be produced and secreted in the process of acute inflammation, inducing a significant activation of $\mathrm{T}$ cell-mediated immune reactions $[1,88]$. However, a long-term secretion and maintenance of the same mediators during chronic inflammation or tumor progression stimulates MDSC generation, enrichment and activation, leading to the inhibition of $\mathrm{T}$ cell functions as a feedback mechanism. In particular, although IFN- $\gamma$ is known to be released by activated T cells and is considered as one of the major mediators of anti-tumor T cell-dependent immune responses [89], it may also stimulate tumor promotion. Thus, long-term production of IFN- $\gamma$ under the sustained antigenic $\mathrm{T}$ cell stimulation results in the stimulation of NO production by MDSCs that represent an important mechanism of their immunosuppressive activity $[1-3,18,23,90]$. Moreover, it has been recently reported that IFN- $\gamma$ produced by $\mathrm{CD} 8^{+} \mathrm{T}$ cells strongly upregulated the expression of PD-L1, which could drastically suppress anti-tumor function of PD- $1^{+}$T cells infiltrating tumor lesions [17,91]. Importantly, a signaling through PD-L1/PD-1 interaction has recently been attributed to one of the major mechanisms of MDSC immunosuppressive function [16]. Interestingly, the upregulation of PD-L1 expression on MDSCs in tumor-bearing hosts may be also strongly stimulated by HIF-1 $\alpha$ under hypoxia conditions [86] that were earlier reported to activate other immunosuppressive mechanisms of MDSCs [85].

Taken together, inflammatory mediators regulate MDSC expansion, migration and activation in a combinatorial and dose-dependent manner (Figure 1). Moreover, being delivered distantly to various organs in the soluble form or by tumor-derived extracellular vesicles, they can pathologically change myelopoiesis and even convert normal monocytes into highly immunosuppressive MDSCs [1,3,18,23,92].

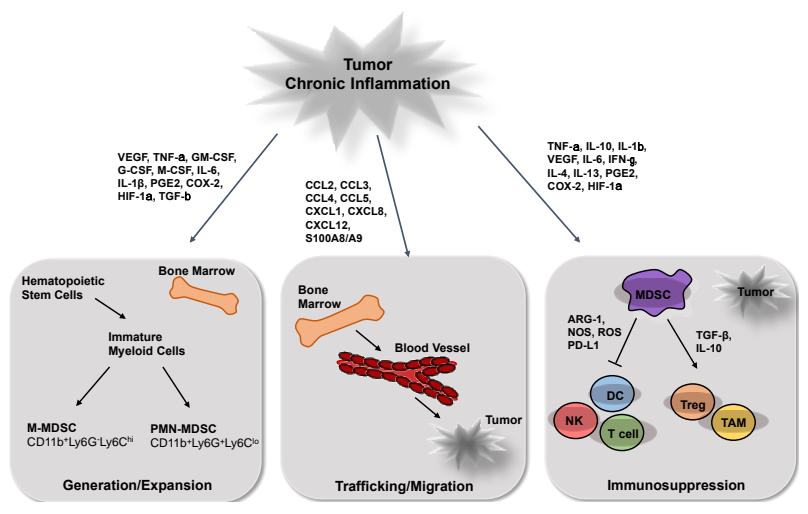

Figure 1. Chronic inflammatory factors stimulate myeloid-derived suppressor cells (MDSC) generation, migration and activation of immunosuppressive functions at the tumor site. Various cytokines and growth factors produced by tumor and stroma cells (such as VEGF, GM-CSF, IL-1 $\beta$, IL-6, HIF- $1 \alpha$, TGF- $\beta$, COX-2, etc.) induce MDSC generation and expansion. Chemokines (like CCL2, CCL3, CCL4, CCL5, CXCL1, CXCL8, etc.) stimulate migration of MDSCs into the tumor microenvironment. At the tumor site, MDSCs undergo activation (via TNF- $\alpha$, IL-10, IL-1 $\beta$, IL-6, IFN- $\gamma$, COX-2, HIF-1 $\alpha$, etc.) and strongly inhibit anti-tumor reactivity of DC, T and NK cells. 


\section{MDSCs Stimulate Tumor Progression}

There is growing evidence that MDSCs are not only induced, recruited and activated by tumor-derived factors but can also directly support tumor development, neovascularization and metastasis [1-3,30,93] (Figure 2). These cells were demonstrated to produce VEGF and basic fibroblast growth factor (bFGF) to promote tumor neoangiogenesis [94-96]. MDSCs also participated in tumor neovascularization together with vascular endothelial progenitor cells (EPCs), which are found in different tumor models $[95,97]$. Moreover, it has been found that MDSCs could even directly incorporate into tumor endothelia, displaying endothelial cell morphology and expressing VEGFR2, a marker for endothelial cells [94].

Furthermore, MDSCs were demonstrated to promote tumor invasion and metastasis by two mechanisms: (i) elevated production of multiple matrix metalloproteinases (MMPs), playing a major role in matrix degradation, and chemokines to create a pre-metastatic environment $[95,98,99]$, and (ii) fusion with tumor cells' MDSCs promoting the metastatic process [100,101]. Indeed, MDSCs have been shown to infiltrate pre-invasive cancer lesions and to be enriched at the invasive frontier of human cancers $[94,102]$. In these lesions, MDSCs were able to produce S100A8 and S100A9 induced by VEGF and TGF- $\beta$ [98]. S100A8/A9 inflammatory proteins have been found not only to attract MDSCs into the tumor microenvironment and enhance their immunosuppressive activity but also to promote the activation of MAPK and NF- $\mathrm{KB}$ signaling pathways in tumor cells, stimulating thereby the tumor progression $[83,103,104]$.

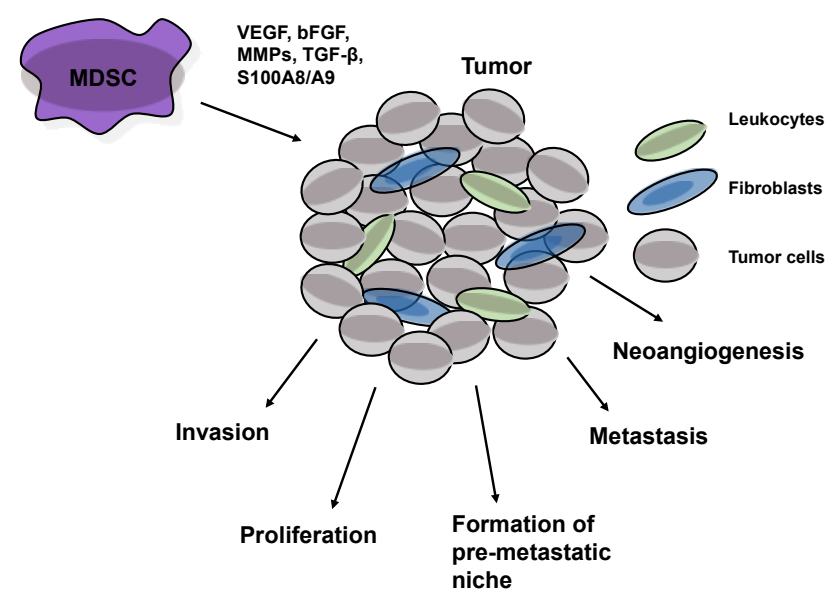

Figure 2. MDSCs support tumor development and metastasis. Soluble factors secreted by MDSCs (such as MMPs, VEGF, TGF- $\beta$, etc.) can stimulate tumor neovascularization, invasion, proliferation and metastasis.

\section{Neutralizing Immunosuppression Induced by MDSCs}

A possibility to decrease MDSC numbers and/or immunosuppressive activities leading to the tumor growth delay and the survival prolongation was already demonstrated both in animal models and in cancer patients [6-10,105]. For this purpose, three major strategies were applied: (i) normalization of myelopoiesis; (ii) MDSC depletion or blocking their expansion and activation; and (iii) inhibition of MDSC immunosuppressive functions (Table 1).

Table 1. Therapeutic strategies to inhibit MDSC immunosuppressive activity.

\begin{tabular}{lc}
\hline \multicolumn{1}{c}{ Therapeutic Strategies } & References \\
\hline 1. Prevention of MDSC generation and migration & {$[106-120]$} \\
2. MDSC depletion or blocking their expansion and activation & {$[120-124]$} \\
3. Inhibition of MDSC immunosuppressive functions & {$[125-131]$} \\
\hline
\end{tabular}


Normalization of myelopoiesis includes the prevention of MDSC generation from bone marrow progenitors and the induction of further MDSC differentiation towards mature DCs and macrophages. One of the key targets in preventing MDSC formation is SCF $[106,107,132]$. The knockdown of SCF with siRNA and inhibition of SCF signaling by anti-c-kit antibodies or with tyrosine kinase inhibitors like sunitinib and sorafenib have been demonstrated to reduce MDSC frequencies in the human bone marrow cells in vitro as well as in murine models of colon and Lewis lung carcinoma that was associated with enhanced anti-tumor reactivity, tumor regression and prolonged survival. In addition, sunitinib has been shown to reverse the MDSC accumulation in patients with renal cell carcinoma (RCC) resulting in the restoration of Th1 cells and a decrease in regulatory T cells [107]. This beneficial effect of sunitinib effect was also detected in the murine RCC model correlated with the suppression of MDSC functions [106]. It has been also reported that the selective pharmacologic inhibition of CSF1R signaling resulted in the decreased tumor angiogenesis associated with reduced recruitment of MDSCs into the tumor site [108]. Moreover, the blockade of CSF1R signaling was found not only to block the MDSC trafficking to tumor lesions but also improve the efficacy of radiotherapy in the prostate cancer model [109]. Furthermore, a recent publication demonstrated that ibrutinib as an irreversible inhibitor of Bruton's tyrosine kinase was able to impair MDSCs' accumulation in a murine breast cancer model and reduce their immunosuppressive activity reflected by decreased production of NO and expression of indolamine 2,3-dioxygenase [110].

MDSC differentiation into mature myeloid cells could be achieved by the administration of all-trans-retinoic acid (ATRA) [111-113] and ultra-low non-cytotoxic doses of chemotherapeutic paclitaxel [114,115]. Although retinoic acid receptors (RAR and RXR) are expressed on various cell types, $R A R \alpha$ and $R X R \alpha$ are expressed predominantly on myeloid cells [116]. The combination of ATRA with G-CSF was shown to drive granulocyte differentiation, whereas its combination with Vitamin D stimulated monocyte development [116]. The combination of ATRA with IL-2 administration resulted in a profound decrease in the frequency of circulating MDSCs, in the improvement of DC functions, and tumor-specific T cell reactivity in patients with metastatic RCC [113]. Another publication reported that ATRA administration into tumor-bearing mice together with human papilloma virus (HPV) therapeutic vaccination decreased MDSC frequencies and functions in the murine HPV-tumor model associated with the activation of tumor-specific T cells and with anti-tumor effects [117]. In addition, the beneficial effect of ATRA applied in combination with DC vaccination has been documented in the clinical trial in the cohort of patients with advanced stage small cell lung cancer [118].

The application of paclitaxel at ultra-low doses to normal mice led to the reduction in the

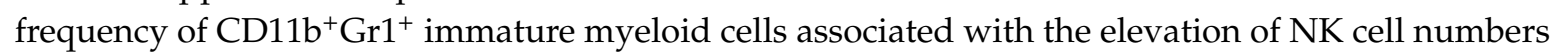
and their ability to produce IFN- $\gamma$ [119]. Moreover, paclitaxel enhanced the efficiency of peptide vaccination in these mice [119]. In melanoma bearing ret transgenic mice, paclitaxel administration induced a significant inhibition of chronic inflammatory factors and MDSC frequencies and functions in melanoma lesion correlated with a partial recovery of tumor-specific $\mathrm{T}$ cell responses, leading to profound anti-melanoma effects [115]. Upon the treatment of in vitro generated MDSCs with nanomolar concentrations of paclitaxel, they were demonstrated to differentiate towards DCs in a TLR-4-independent manner [114]. In contrast, paclitaxel failed to induce MDSC apoptosis or affect the MDSC generation from the bone marrow precursor cells.

Direct selective elimination of MDSCs can be achieved by the administration of gemcitabine [120] or 5-fluorouracil [121]. Using several cancer models, it has been found that these chemotherapeutical agents depleted MDSCs without toxic effects on other leukocyte subsets, resulting in markedly enhanced anti-tumor efficacy. The prevention of MDSC trafficking towards tumor lesions is based on the targeting of tumor-derived chemokines. Prostate and breast carcinomas, melanomas, colorectal cancer and Lewis lung carcinoma were found to produce various chemokines (including CCL2, CCL3, CCL4, CCL5, etc.), which were described to attract MDSCs and to maintain their suppressive activity [76-80]. Direct CCL2 targeting [122] or the inhibition of its production [123] has been reported 
to decrease the frequency of tumor-infiltrating MDSCs, to restrict neoangiogenesis and to suppress the growth of transplantable tumors.

Once migrated into the tumor microenvironment, MDSCs may affect anti-tumor reactivity of $\mathrm{T}$ and NK cells by various mechanisms $[1-4,18,23,24]$. Among them, the activation of inducible NO synthase (iNOS) and arginase (ARG)-1 plays a key role. Production catalyzed by iNOS was not demonstrated (i) to induce a nitration of T cell receptors in situ [1-3,6]; (ii) to target distinct signaling pathways resulting in the inhibition of cytokine production required for T cell functions [14]; (iii) and to mediate $\mathrm{T}$ cell apoptosis $[14,124]$. The activation ARG-1 induced a deprivation of L-arginine, which is not produced by $\mathrm{T}$ cells and is critical for protein synthesis [133]. Importantly, the blockade of the activity of phosphodiesterase (PDE)-5 has been reported to increase intracellular concentrations of cyclic guanosine monophosphate (cGMP) resulting in the inhibition of both iNOS and ARG-1 activities [134]. Based on these observations, PDE-5 inhibitors such as sildenafil, tadalafil and vardenafil have been proposed for the inhibition of MDSC immunosuppressive functions $[125,134]$. The chronic sildenafil administration with the drinking water was reported to cause a significant reduction in the NO production and in the expression of ARG-1 associated with the restoration of tumor-specific CD8 $\mathrm{T}$ cell responses and a significantly prolonged survival of tumor-bearing mice $[27,125,134]$. Moreover, sildenafil could strongly diminish chronic inflammation in the metastatic lymph nodes indicated by a decrease in the production of IL-1 $\beta$, IL-6, VEGF, GM-CSF, CCL2, CCL3 and S100A9 [27]. In addition, the successful application of tadalafil in a patient with end-stage relapsed/refractory multiple myeloma [126] as well as in clinical trials involving head and neck cancer patients has been recently documented $[127,128]$.

Besides PDE-5 inhibitors, the activity of iNOS and ARG-1 was found to be blocked by corresponding inhibitors [70,125] or by nitroaspirin [129] leading to the stimulation of $\mathrm{T}$ cell functions and anti-tumor effects. Interestingly, some agents that prevented MDSC migration towards tumors could also inhibit MDSC immunosuppressive function. In particular, the inhibition of COX-2 activity and PGE2 production has been reported to reduce the CXCR4/CXCL12 and CXCR1-CXCR2/CXCL8-mediated MDSC trafficking [78,79] and to impair the MDSC-mediated immunosuppression by reducing the production of ROS and NO or the expression of ARG-1 in these cells [130].

MDSC numbers and the immunosuppressive pattern could be also modulated by negative checkpoint inhibitors that are widely used for tumor immunotherapy. Thus, in melanoma patients treated with Ipilimumab, decreased amounts and immunosuppressive functionality of both monocytic and polymorphonuclear MDSCs correlated with beneficial therapeutic effects [65,131,135-137]. Moreover, non-responding patients showed also elevated serum levels of inflammatory molecules S100A8/A9 and high mobility group box 1 (HMGB1), suggesting that MDSC and chronic inflammatory factors can be not only therapeutic targets in cancer patients but also serve as new biomarkers detecting the group of advanced melanoma patients who may benefit from Ipilimumab therapy [135].

\section{Conclusions}

The role of MDSCs in tumor progression is well-documented. These cells were found to be generated only under pathological conditions such as chronic inflammation and cancer. Established tumors are able to produce multiple factors that impair the myelopoiesis favoring the MDSC formation, trafficking to the tumor site and their activation. Being one of the most potent immunosuppressive cells, MDSCs promote tumor progression by inhibiting the anti-tumor functions of T and NK cells. On the other hand, MDSCs are able to stimulate tumor development directly by promoting neovascularization and tumor cell invasion and by creating a pre-metastatic environment. It is obvious that the efficiency of different immunotherapeutic strategies will be strictly dependent on the neutralization of MDSC-induced immunosuppression. Even adoptively transferred activated tumor-specific CD8 T cells either will develop anergy or even undergo apoptosis, being migrated into an immunosuppressive tumor microenvironment. Therefore, understanding the mechanisms and key regulators of MDSC 
generation, trafficking and activation is critically important to overcoming immunosuppression and achieving better therapeutic results in cancer patients.

Acknowledgments: This work was supported by grants from the German Research Council (RTG2099 to Jochen Utikal, Viktor Umansky and DFG GE-2152/1-2 to Christoffer Gebhardt), the DKFZ-MOST Cooperation in Cancer Research (CA157 to Viktor Umansky) and the German Cancer Aid (109312 to Jochen Utikal). This work was kindly backed by the COST Action BM1404 Mye-EUNITER (www.mye-euniter.eu). COST is supported by the EU Framework Program Horizon 2020.

Conflicts of Interest: The authors declare no conflict of interest.

\section{Abbreviations}

The following abbreviations are used in this manuscript:

$\begin{array}{ll}\text { ARG } & \text { arginase } \\ \text { ATRA } & \text { all-trans-retinoic acid } \\ \text { CCL } & \text { C-C motif ligand } \\ \text { CCR } & \text { C-C motif receptor } \\ \text { cGMP } & \text { cyclic guanosine monophosphate } \\ \text { COX } & \text { cyclooxygenase } \\ \text { CXCL } & \text { C-X-C motif ligand } \\ \text { DCs } & \text { dendritic cells } \\ \text { EPCs } & \text { endothelial progenitor cells } \\ \text { G-CSF } & \text { granulocyte colony-stimulating factor } \\ \text { GM-CSF } & \text { granulocyte-macrophage colony-stimulating factor } \\ \text { HIF-1 } \alpha & \text { hypoxia-inducible factor-1 } \alpha \\ \text { HMGB1 } & \text { high mobility group box 1 } \\ \text { HPV } & \text { human papilloma virus } \\ \text { IFN } & \text { interferon } \\ \text { IL } & \text { interleukin } \\ \text { iNOS } & \text { inducible NO synthase } \\ \text { M } & \text { monocytic } \\ \text { M-CSF } & \text { macrophage colony-stimulating factor } \\ \text { M-CSF } & \text { macrophage colony-stimulating factor } \\ \text { MDSCs } & \text { myeloid-derived suppressor cells } \\ \text { MMPs } & \text { matrix metalloproteinases } \\ \text { NO } & \text { nitric oxide } \\ \text { PD } & \text { programmed death } \\ \text { PDE } & \text { phosphodiesterase } \\ \text { PG } & \text { prostaglandin } \\ \text { PMN } & \text { polymorphonuclear } \\ \text { RCC } & \text { renal cell carcinoma } \\ \text { ROS } & \text { reactive oxygen species } \\ \text { SCF } & \text { stem cell factor } \\ \text { STAT } & \text { signal transducer and activator of transcription } \\ \text { TAMs } & \text { tumor-associated macrophages } \\ \text { TCR } & \text { T cell receptor } \\ \text { TGF } & \text { transforming growth factor } \\ \text { TLR } & \text { toll-like receptor } \\ \text { TNF } & \text { tumor necrosis factor } \\ \text { Treg } & \text { regulatory T cells } \\ \text { VEGF } & \text { vascular endothelial growth factor } \\ & \end{array}$

\section{References}

1. Gabrilovich, D.I.; Ostrand-Rosenberg, S.; Bronte, V. Coordinated regulation of myeloid cells by tumours. Nat. Rev. Immunol. 2012, 12, 253-268. [CrossRef] [PubMed]

2. Kumar, V.; Patel, S.; Tcyganov, E.; Gabrilovich, D.I. The Nature of Myeloid-Derived Suppressor Cells in the Tumor Microenvironment. Trends Immunol. 2016, 37, 208-220. [CrossRef] [PubMed]

3. Parker, K.H.; Beury, D.W.; Ostrand-Rosenberg, S. Myeloid-Derived Suppressor Cells: Critical Cells Driving Immune Suppression in the Tumor Microenvironment. Adv. Cancer Res. 2015, 128, 95-139. [PubMed]

4. Meirow, Y.; Kanterman, J.; Baniyash, M. Paving the Road to Tumor Development and Spreading: Myeloid-Derived Suppressor Cells are Ruling the Fate. Front. Immunol. 2015. [CrossRef] [PubMed] 
5. Bronte, V.; Brandau, S.; Chen, S.H.; Colombo, M.P.; Frey, A.B.; Greten, T.F.; Mandruzzato, S.; Murray, P.J.; Ochoa, A.; Ostrand-Rosenberg, S.; et al. Recommendations for myeloid-derived suppressor cell nomenclature and characterization standards. Nat. Commun. 2016. [CrossRef] [PubMed]

6. De Sanctis, F.; Solito, S.; Ugel, S.; Molon, B.; Bronte, V.; Marigo, I. MDSCs in cancer: Conceiving new prognostic and therapeutic targets. Biochim. Biophys. Acta 2016, 1865, 35-48. [CrossRef] [PubMed]

7. Solito, S.; Marigo, I.; Pinton, L.; Damuzzo, V.; Mandruzzato, S.; Bronte, V. Myeloid-derived suppressor cell heterogeneity in human cancers. Ann. N.Y. Acad. Sci. 2014, 1319, 47-65. [CrossRef] [PubMed]

8. Filipazzi, P.; Huber, V.; Rivoltini, L. Phenotype, function and clinical implications of myeloid-derived suppressor cells in cancer patients. Cancer Immunol. Immunother. 2012, 61, 255-263. [CrossRef] [PubMed]

9. Poschke, I.; Kiessling, R. On the armament and appearances of human myeloid-derived suppressor cells. Clin. Immunol. 2012, 144, 250-268. [CrossRef] [PubMed]

10. Marvel, D.; Gabrilovich, D.I. Myeloid-derived suppressor cells in the tumor microenvironment: Expect the unexpected. J. Clin. Invest. 2015, 125, 3356-3364. [CrossRef] [PubMed]

11. Ostrand-Rosenberg, S. Myeloid-derived suppressor cells: More mechanisms for inhibiting antitumor immunity. Cancer Immunol. Immunother. 2010, 59, 1593-1600. [CrossRef] [PubMed]

12. Raber, P.; Ochoa, A.C.; Rodríguez, P.C. Metabolism of L-arginine by myeloid-derived suppressor cells in cancer: Mechanisms of T cell suppression and therapeutic perspectives. Immunol. Invest. 2012, 41, 614-634. [CrossRef] [PubMed]

13. Molon, B.; Ugel, S.; Del Pozzo, F.; Soldani, C.; Zilio, S.; Avella, D.; De Palma, A.; Mauri, P.; Monegal, A.; Rescigno, M.; et al. Chemokine nitration prevents intratumoral infiltration of antigen-specific $\mathrm{T}$ cells. J. Exp. Med. 2011, 208, 1949-1962. [CrossRef] [PubMed]

14. Bogdan, C. Nitric oxide and the immune response. Nat. Immunol. 2001, 2, 907-916. [CrossRef] [PubMed]

15. Pickup, M.; Novitskiy, S.; Moses, H.L. The roles of TGF $\beta$ in the tumour microenvironment. Nat. Rev. Cancer 2013, 13, 788-799. [CrossRef] [PubMed]

16. Noman, M.Z.; Desantis, G.; Janji, B.; Hasmim, M.; Karray, S.; Dessen, P.; Bronte, V.; Chouaib, S. PD-L1 is a novel direct target of HIF-1 $\alpha$, and its blockade under hypoxia enhanced MDSC-mediated T cell activation. J. Exp. Med. 2014, 211, 781-790. [CrossRef] [PubMed]

17. Gajewski, T.F.; Woo, S.R.; Zha, Y.; Spaapen, R.; Zheng, Y.; Corrales, L.; Spranger, S. Cancer immunotherapy strategies based on overcoming barriers within the tumor microenvironment. Curr. Opin. Immunol. 2013, 25, 268-276. [CrossRef] [PubMed]

18. Umansky, V.; Sevko, A. Melanoma-induced immunosuppression and its neutralization. Semin. Cancer Biol. 2012, 22, 319-326. [CrossRef] [PubMed]

19. Tartour, E.; Pere, H.; Maillere, B.; Terme, M.; Merillon, N.; Taieb, J.; Sandoval, F.; Quintin-Colonna, F.; Lacerda, K.; Karadimou, A.; et al. Angiogenesis and immunity: a bidirectional link potentially relevant for the monitoring of antiangiogenic therapy and the development of novel therapeutic combination with immunotherapy. Cancer Metastasis Rev. 2011, 30, 83-95. [CrossRef] [PubMed]

20. Binsfeld, M.; Muller, J.; Lamour, V.; De Veirman, K.; De Raeve, H.; Bellahcène, A.; Van Valckenborgh, E.; Baron, F.; Beguin, Y.; Caers, J.; et al. Granulocytic myeloid-derived suppressor cells promote angiogenesis in the context of multiple myeloma. Oncotarget 2016. [CrossRef] [PubMed]

21. Qu, P.; Yan, C.; Du, H. Matrix metalloproteinase 12 overexpression in myeloid lineage cells plays a key role in modulating myelopoiesis, immune suppression, and lung tumorigenesis. Blood 2011, 117, 4476-4489. [CrossRef] [PubMed]

22. Pan, P.Y.; Ma, G.; Weber, K.J.; Ozao-Choy, J.; Wang, G.; Yin, B.; Divino, C.M.; Chen, S.H. Immune stimulatory receptor CD40 is required for T-cell suppression and $\mathrm{T}$ regulatory cell activation mediated by myeloid-derived suppressor cells in cancer. Cancer Res. 2010, 70, 99-108. [CrossRef] [PubMed]

23. Kanterman, J.; Sade-Feldman, M.; Baniyash, M. New insights into chronic inflammation-induced immunosuppression. Semin. Cancer Biol. 2012, 22, 307-318. [CrossRef] [PubMed]

24. Umansky, V.; Sevko, A.; Gebhardt, C.; Utikal, J. Myeloid-derived suppressor cells in malignant melanoma. J. Dtsch. Dermatol. Ges. 2014, 12, 1021-1027. [CrossRef] [PubMed]

25. Grivennikov, S.I.; Greten, F.R.; Karin, M. Immunity, inflammation, and cancer. Cell 2010, 140, 883-899. [CrossRef] [PubMed] 
26. Navarini-Meury, A.A.; Conrad, C. Melanoma and innate immunity-Active inflammation or just erroneous attraction?: Melanoma as the source of leukocyte-attracting chemokines. Semin. Cancer Biol. 2009, 19, 84-91. [CrossRef] [PubMed]

27. Meyer, C.; Sevko, A.; Ramacher, M.; Bazhin, A.V.; Falk, C.S.; Osen, W.; Borrello, I.; Kato, M.; Schadendorf, D.; Baniyash, M.; et al. Chronic inflammation promotes myeloid-derived suppressor cell activation blocking antitumor immunity in transgenic mouse melanoma model. Proc. Natl. Acad. Sci. USA 2011, 108, 17111-17116. [CrossRef] [PubMed]

28. Katanov, C.; Lerrer, S.; Liubomirski, Y.; Leider-Trejo, L.; Meshel, T.; Bar, J.; Feniger-Barish, R.; Kamer, I.; Soria-Artzi, G.; Kahani, H.; et al. Regulation of the inflammatory profile of stromal cells in human breast cancer: prominent roles for TNF- $\alpha$ and the NF-кB pathway. Stem Cell Res. Ther. 2015. [CrossRef] [PubMed]

29. Labrousse, A.L.; Ntayi, C.; Hornebeck, W.; Bernard, P. Stromal reaction in cutaneous melanoma. Crit. Rev. Oncol. Hematol. 2004, 49, 269-275. [CrossRef] [PubMed]

30. Bunt, S.K.; Yang, L.; Sinha, P.; Clements, V.K.; Leips, J.; Ostrand-Rosenberg, S. Reduced inflammation in the tumor microenvironment delays the accumulation of myeloid-derived suppressor cells and limits tumor progression. Cancer Res. 2007, 67, 10019-10026. [CrossRef] [PubMed]

31. Barreda, D.R.; Hanington, P.C.; Belosevic, M. Regulation of myeloid development and function by colony stimulating factors. Dev. Comp. Immunol. 2004, 28, 509-554. [CrossRef] [PubMed]

32. Hamilton, J.A. GM-CSF as a target in inflammatory/autoimmune disease: Current evidence and future therapeutic potential. Expert Rev. Clin. Immunol. 2015, 11, 457-465. [CrossRef] [PubMed]

33. Revoltella, R.P.; Menicagli, M.; Campani, D. Granulocyte-macrophage colony-stimulating factor as an autocrine survival-growth factor in human gliomas. Cytokine 2012, 57, 347-359. [CrossRef] [PubMed]

34. Dolcetti, L.; Peranzoni, E.; Ugel, S.; Marigo, I.; Fernandez Gomez, A.; Mesa, C.; Geilich, M.; Winkels, G.; Traggiai, E.; Casati, A.; et al. Hierarchy of immunosuppressive strength among myeloid-derived suppressor cell subsets is determined by GM-CSF. Eur. J. Immunol. 2010, 40, 22-35. [CrossRef] [PubMed]

35. Morales, J.K.; Kmieciak, M.; Knutson, K.L.; Bear, H.D.; Manjili, M.H. GM-CSF is one of the main breast tumor-derived soluble factors involved in the differentiation of CD11b-Gr1-bone marrow progenitor cells into myeloid-derived suppressor cells. Breast Cancer Res. Treat. 2010, 123, 39-49. [CrossRef] [PubMed]

36. Ribechini, E.; Greifenberg, V.; Sandwick, S.; Lutz, M.B. Subsets, expansion and activation of myeloid-derived suppressor cells. Med. Microbiol. Immunol. 2010, 199, 273-281. [CrossRef] [PubMed]

37. Lechner, M.G.; Liebertz, D.J.; Epstein, A.L. Characterization of cytokine-induced myeloid-derived suppressor cells from normal human peripheral blood mononuclear cells. J. Immunol. 2010, 185, 2273-2284. [CrossRef] [PubMed]

38. Marigo, I.; Bosio, E.; Solito, S.; Mesa, C.; Fernandez, A.; Dolcetti, L.; Ugel, S.; Sonda, N.; Bicciato, S.; Falisi, E.; et al. Tumor-induced tolerance and immune suppression depend on the C/EBP $\beta$ transcription factor. Immunity 2010, 32, 790-802. [CrossRef] [PubMed]

39. Casella, I.; Feccia, T.; Chelucci, C.; Samoggia, P.; Castelli, G.; Guerriero, R.; Parolini, I.; Petrucci, E.; Pelosi, E.; Morsilli, O.; et al. Autocrine-paracrine VEGF loops potentiate the maturation of megakaryocytic precursors through Flt1 receptor. Blood 2003, 101, 1316-1323. [CrossRef] [PubMed]

40. Söderberg, S.S.; Karlsson, G.; Karlsson, S. Complex and context dependent regulation of hematopoiesis by TGF- $\beta$ superfamily signaling. Ann. N.Y. Acad. Sci. 2009, 1176, 55-69. [CrossRef] [PubMed]

41. Johnson, B.; Osada, T.; Clay, T.; Lyerly, H.; Morse, M. Physiology and therapeutics of vascular endothelial growth factor in tumor immunosuppression. Curr. Mol. Med. 2009, 9, 702-707. [CrossRef] [PubMed]

42. Kusmartsev, S.; Eruslanov, E.; Kübler, H.; Tseng, T.; Sakai, Y.; Su, Z.; Kaliberov, S.; Heiser, A.; Rosser, C.; Dahm, P.; et al. Oxidative stress regulates expression of VEGFR1 in myeloid cells: Link to tumor-induced immune suppression in renal cell carcinoma. J. Immunol. 2008, 181, 346-353. [CrossRef] [PubMed]

43. Flavell, R.A.; Sanjabi, S.; Wrzesinski, S.H.; Licona-Limón, P. The polarization of immune cells in the tumour environment by TGFbeta. Nat. Rev. Immunol. 2010, 10, 554-567. [CrossRef] [PubMed]

44. Majka, M.; Janowska-Wieczorek, A.; Ratajczak, J.; Ehrenman, K.; Pietrzkowski, Z.; Kowalska, M.A.; Gewirtz, A.M.; Emerson, S.G.; Ratajczak, M.Z. Numerous growth factors, cytokines, and chemokines are secreted by human CD34(+) cells, myeloblasts, erythroblasts, and megakaryoblasts and regulate normal hematopoiesis in an autocrine/paracrine manner. Blood 2001, 97, 3075-3085. [CrossRef] [PubMed]

45. Apte, R.N.; Voronov, E. Is interleukin-1 a good or bad 'guy' in tumor immunobiology and immunotherapy? Immunol. Rev. 2008, 222, 222-241. [CrossRef] [PubMed] 
46. Garlanda, C.; Dinarello, C.A.; Mantovani, A. The interleukin-1 family: Back to the future. Immunity 2013, 39, 1003-1018. [CrossRef] [PubMed]

47. Elkabets, M.; Ribeiro, V.S.; Dinarello, C.A.; Ostrand-Rosenberg, S.; Di Santo, J.P.; Apte, R.N.; Vosshenrich, C.A. IL-1 $\beta$ regulates a novel myeloid-derived suppressor cell subset that impairs NK cell development and function. Eur. J. Immunol. 2010, 40, 3347-3357. [CrossRef] [PubMed]

48. Tu, S.; Bhagat, G.; Cui, G.; Takaishi, S.; Kurt-Jones, E.A.; Rickman, B.; Betz, K.S.; Penz-Oesterreicher, M.; Bjorkdahl, O.; Fox, J.G.; et al. Overexpression of interleukin-1beta induces gastric inflammation and cancer and mobilizes myeloid-derived suppressor cells in mice. Cancer Cell 2008, 14, 408-419. [CrossRef] [PubMed]

49. Kao, A.P.; Wang, K.H.; Long, C.Y.; Chai, C.Y.; Tsai, C.F.; Hsieh, T.H.; Hsu, C.Y.; Chang, C.C.; Lee, J.N.; Tsai, E.M. Interleukin-1 $\beta$ induces cyclooxygenase-2 expression and promotes the invasive ability of human mesenchymal stem cells derived from ovarian endometrioma. Fertil. Steril. 2011, 96, 678-684. [CrossRef] [PubMed]

50. Eruslanov, E.; Daurkin, I.; Ortiz, J.; Vieweg, J.; Kusmartsev, S. Pivotal Advance: Tumor-mediated induction of myeloid-derived suppressor cells and M2-polarized macrophages by altering intracellular PGE2 catabolism in myeloid cells. J. Leukoc. Biol. 2010, 88, 39-48. [CrossRef] [PubMed]

51. Sinha, P.; Clements, V.K.; Fulton, A.M.; Ostrand-Rosenberg, S. Prostaglandin E2 promotes tumor progression by inducing myeloid-derived suppressor cells. Cancer Res. 2007, 67, 4507-4513. [CrossRef] [PubMed]

52. Ledesma, E.; Martvnez, I.; Cordova, Y.; Rodríguez-Sosa, M.; Monroy, A.; Mora, L.; Soto, I.; Ramos, G.; Weiss, B.; Santiago Osorio, E. Interleukin-1 $\beta$ (IL-1 $\beta$ ) induces tumor necrosis factor alpha (TNF- $\alpha$ ) expression on mouse myeloid multipotent cell line 32D cl3 and inhibits their proliferation. Cytokine 2004, 26, 66-72. [CrossRef] [PubMed]

53. Sade-Feldman, M.; Kanterman, J.; Ish-Shalom, E.; Elnekave, M.; Horwitz, E.; Baniyash, M. Tumor necrosis factor- $\alpha$ blocks differentiation and enhances suppressive activity of immature myeloid cells during chronic inflammation. Immunity 2013, 38, 541-554. [CrossRef] [PubMed]

54. Yang, F.; Li, Y.; Wu, T.; Na, N.; Zhao, Y.; Li, W.; Han, C.; Zhang, L.; Lu, J.; Zhao, Y. TNF $\alpha$-induced M-MDSCs promote transplant immune tolerance via nitric oxide. J. Mol. Med. 2016, 94, 911-920. [CrossRef] [PubMed]

55. Stathopoulos, G.T.; Sherrill, T.P.; Karabela, S.P.; Goleniewska, K.; Kalomenidis, I.; Roussos, C.; Fingleton, B.; Yull, F.E.; Peebles, R.S., Jr.; Blackwell, T.S. Host-derived interleukin-5 promotes adenocarcinoma-induced malignant pleural effusion. Am. J. Respir. Crit. Care Med. 2010, 182, 1273-1281. [CrossRef] [PubMed]

56. Gabitass, R.F.; Annels, N.E.; Stocken, D.D.; Pandha, H.A.; Middleton, G.W. Elevated myeloid-derived suppressor cells in pancreatic, esophageal and gastric cancer are an independent prognostic factor and are associated with significant elevation of the Th2 cytokine interleukin-13. Cancer Immunol. Immunother. 2011, 60, 1419-1430. [CrossRef] [PubMed]

57. Neurath, M.F.; Finotto, S. IL-6 signaling in autoimmunity, chronic inflammation and inflammation-associated cancer. Cytokine Growth Factor Rev. 2011, 22, 83-89. [CrossRef] [PubMed]

58. Wu, C.T.; Hsieh, C.C.; Lin, C.C.; Chen, W.C.; Hong, J.H.; Chen, M.F. Significance of IL-6 in the transition of hormone-resistant prostate cancer and the induction of myeloid-derived suppressor cells. J. Mol. Med. 2012, 90, 1343-1355. [CrossRef] [PubMed]

59. Sonda, N.; Chioda, M.; Zilio, S.; Simonato, F.; Bronte, V. Transcription factors in myeloid-derived suppressor cell recruitment and function. Curr. Opin. Immunol. 2011, 23, 279-285. [CrossRef] [PubMed]

60. Yu, H.; Pardoll, D.; Jove, R. STATs in cancer inflammation and immunity: A leading role for STAT3. Nat. Rev. Cancer 2009, 9, 798-809. [CrossRef] [PubMed]

61. Sumida, K.; Wakita, D.; Narita, Y.; Masuko, K.; Terada, S.; Watanabe, K.; Satoh, T.; Kitamura, H.; Nishimura, T. Anti-IL-6 receptor $\mathrm{mAb}$ eliminates myeloid-derived suppressor cells and inhibits tumor growth by enhancing T-cell responses. Eur. J. Immunol. 2012, 42, 2060-2072. [CrossRef] [PubMed]

62. Schilling, B.; Sucker, A.; Griewank, K.; Zhao, F.; Weide, B.; Görgens, A.; Giebel, B.; Schadendorf, D.; Paschen, A. Vemurafenib reverses immunosuppression by myeloid derived suppressor cells. Int. J. Cancer 2013, 133, 1653-1663. [CrossRef] [PubMed]

63. Jordan, K.R.; Amaria, R.N.; Ramirez, O.; Callihan, E.B.; Gao, D.; Borakove, M.; Manthey, E.; Borges, V.F.; McCarter, M.D. Myeloid-derived suppressor cells are associated with disease progression and decreased overall survival in advanced-stage melanoma patients. Cancer Immunol. Immunother. 2013, 62, 1711-1722. [CrossRef] [PubMed] 
64. Weide, B.; Martens, A.; Zelba, H.; Derhovanessian, E.; Bailur, J.K.; Kyzirakos, C.; Pflugfelder, A.; Eigentler, T.K.; Di Giacomo, A.M.; Maio, M.; et al. Myeloid-derived suppressor cells predict survival of advanced melanoma patients: comparison with regulatory T cells and NY-ESO-1- or Melan-A-specific T cells. Clin. Cancer Res. 2014, 20, 1601-1609. [CrossRef] [PubMed]

65. Pico de Coaña, Y.; Poschke, I.; Gentilcore, G.; Mao, Y.; Nyström, M.; Hansson, J.; Masucci, G.V.; Kiessling, R. Ipilimumab treatment results in an early decrease in the frequency of circulating granulocytic myeloid-derived suppressor cells as well as their Arginase1 production. Cancer Immunol. Res. 2013, 1, 158-162. [CrossRef] [PubMed]

66. Jiang, H.; Gebhardt, C.; Umansky, L.; Beckhove, P.; Schulze, T.J.; Utikal, J.; Umansky, V. Elevated chronic inflammatory factors and myeloid-derived suppressor cells indicate poor prognosis in advanced melanoma patients. Int. J. Cancer 2015, 136, 2352-2360. [CrossRef] [PubMed]

67. Wang, L.; Chang, E.W.; Wong, S.C.; Ong, S.M.; Chong, D.Q.; Ling, K.L. Increased myeloid-derived suppressor cells in gastric cancer correlate with cancer stage and plasma S100A8/A9 proinflammatory proteins. J. Immunol. 2013, 190, 794-804. [CrossRef] [PubMed]

68. Solito, S.; Falisi, E.; Diaz-Montero, C.M.; Doni, A.; Pinton, L.; Rosato, A.; Francescato, S.; Basso, G.; Zanovello, P.; Onicescu, G.; et al. A human promyelocytic-like population is responsible for the immune suppression mediated by myeloid-derived suppressor cells. Blood 2011, 118, 2254-2265. [CrossRef] [PubMed]

69. Zhang, B.; Wang, Z.; Wu, L.; Zhang, M.; Li, W.; Ding, J.; Zhu, J.; Wei, H.; Zhao, K. Circulating and tumor-infiltrating myeloid-derived suppressor cells in patients with colorectal carcinoma. PLoS ONE 2013. [CrossRef] [PubMed]

70. Jayaraman, P.; Parikh, F.; Lopez-Rivera, E.; Hailemichael, Y.; Clark, A.; Ma, G.; Cannan, D.; Ramacher, M.; Kato, M.; Overwijk, W.W.; et al. Tumor-expressed inducible nitric oxide synthase controls induction of functional myeloid-derived suppressor cells through modulation of vascular endothelial growth factor release. J. Immunol. 2012, 188, 5365-5376. [CrossRef] [PubMed]

71. Talmadge, J.E.; Gabrilovich, D.I. History of myeloid-derived suppressor cells. Nat. Rev. Cancer 2013, 13, 739-752. [CrossRef] [PubMed]

72. Palomino, D.C.; Marti, L.C. Chemokines and immunity. Einstein 2015, 13, 469-473. [CrossRef] [PubMed]

73. Homey, B.; Muller, A.; Zlotnik, A. Chemokines: Agents for the immunotherapy of cancer? Nature Rev. Immunol. 2002, 2, 175-184. [CrossRef] [PubMed]

74. Lesokhin, A.M.; Hohl, T.M.; Kitano, S.; Cortez, C.; Hirschhorn-Cymerman, D.; Avogadri, F.; Rizzuto, G.A.; Lazarus, J.J.; Pamer, E.G.; Houghton, A.N.; et al. Monocytic CCR2(+) myeloid-derived suppressor cells promote immune escape by limiting activated CD8 T-cell infiltration into the tumor microenvironment. Cancer Res. 2012, 72, 876-886. [CrossRef] [PubMed]

75. Zhang, J.; Patel, L.; Pienta, K.J. CC chemokine ligand 2 (CCL2) promotes prostate cancer tumorigenesis and metastasis. Cytokine Growth Factor Rev. 2010, 21, 41-48. [CrossRef] [PubMed]

76. Izhak, L.; Wildbaum, G.; Weinberg, U.; Shaked, Y.; Alami, J.; Dumont, D.; Friedman, B.; Stein, A.; Karin, N. Predominant expression of CCL2 at the tumor site of prostate cancer patients directs a selective loss of immunological tolerance to CCL2 that could be amplified in a beneficial manner. J. Immunol. 2010, 184, 1092-1101. [CrossRef] [PubMed]

77. Izhak, L.; Wildbaum, G.; Jung, S.; Stein, A.; Shaked, Y.; Karin, N. Dissecting the Autocrine and Paracrine Roles of the CCR2-CCL2 Axis in Tumor Survival and Angiogenesis. PLoS ONE 2012. [CrossRef] [PubMed]

78. Obermajer, N.; Muthuswamy, R.; Odunsi, K.; Edwards, R.P.; Kalinski, P. PGE(2)-induced CXCL12 production and CXCR4 expression controls the accumulation of human MDSCs in ovarian cancer environment. Cancer Res. 2011, 71, 7463-7470. [CrossRef] [PubMed]

79. Kalinski, P. Regulation of immune responses by prostaglandin E2. J. Immunol. 2012, 188, 21-28. [CrossRef] [PubMed]

80. Williams, S.A.; Harata-Lee, Y.; Comerford, I.; Anderson, R.L.; Smyth, M.J.; McColl, S.R. Multiple functions of CXCL12 in a syngeneic model of breast cancer. Mol. Cancer 2010. [CrossRef] [PubMed]

81. Gama, L.; Shirk, E.N.; Russell, J.N.; Carvalho, K.I.; Li, M.; Queen, S.E.; Kalil, J.; Zink, M.C.; Clements, J.E.; Kallas, E.G. Expansion of a subset of CD14highCD16negCCR2low/neg monocytes functionally similar to myeloid-derived suppressor cells during SIV and HIV infection. J. Leukoc. Biol. 2012, 91, 803-816. [CrossRef] [PubMed] 
82. Connolly, M.K.; Mallen-St Clair, J.; Bedrosian, A.S.; Malhotra, A.; Vera, V.; Ibrahim, J.; Henning, J.; Pachter, H.L.; Bar-Sagi, D.; Frey, A.B.; et al. Distinct populations of metastases-enabling myeloid cells expand in the liver of mice harboring invasive and preinvasive intra-abdominal tumor. J. Leukoc. Biol. 2010, 87, 713-725. [CrossRef] [PubMed]

83. Ichikawa, M.; Williams, R.; Wang, L.; Vogl, T.; Srikrishna, G. S100A8/A9 activate key genes and pathways in colon tumor progression. Mol. Cancer Res. 2011, 9, 133-148. [CrossRef] [PubMed]

84. Wang, S.W.; Liu, S.C.; Sun, H.L.; Huang, T.Y.; Chan, C.H.; Yang, C.Y.; Yeh, H.I.; Huang, Y.L.; Chou, W.Y.; Lin, Y.M.; et al. CCL5/CCR5 axis induces vascular endothelial growth factor-Mediated tumor angiogenesis in human osteosarcoma microenvironment. Carcinogenesis 2015, 36, 104-114. [CrossRef] [PubMed]

85. Corzo, C.A.; Condamine, T.; Lu, L.; Cotter, M.J.; Youn, J.I.; Cheng, P.; Cho, H.I.; Celis, E.; Quiceno, D.G.; Padhya, T.; et al. HIF-1 $\alpha$ regulates function and differentiation of myeloid-derived suppressor cells in the tumor microenvironment. J. Exp. Med. 2010, 207, 2439-2453. [CrossRef] [PubMed]

86. Noman, M.Z.; Janji, B.; Hu, S.; Wu, J.C.; Martelli, F.; Bronte, V.; Chouaib, S. Tumor-Promoting Effects of Myeloid-Derived Suppressor Cells Are Potentiated by Hypoxia-Induced Expression of miR-210. Cancer Res. 2015, 75, 3771-3787. [CrossRef] [PubMed]

87. Sawanobori, Y.; Ueha, S.; Kurachi, M.; Shimaoka, T.; Talmadge, J.E.; Abe, J.; Shono, Y.; Kitabatake, M.; Kakimi, K.; Mukaida, N.; et al. Chemokine-mediated rapid turnover of myeloid-derived suppressor cells in tumor-bearing mice. Blood 2008, 111, 5457-5466. [CrossRef] [PubMed]

88. Gasteiger, G.; Rudensky, A.Y. Interactions between innate and adaptive lymphocytes. Nat. Rev. Immunol. 2014, 14, 631-639. [CrossRef] [PubMed]

89. Kaplan, D.H.; Shankaran, V.; Dighe, A.S.; Stockert, E.; Aguet, M.; Old, L.J.; Schreiber, R.D. Demonstration of an interferon gamma-dependent tumor surveillance system in immunocompetent mice. Proc. Natl. Acad. Sci. USA 1998, 95, 7556-7561. [CrossRef] [PubMed]

90. Zaidi, M.R.; Merlino, G. The two faces of interferon- $\gamma$ in cancer. Clin. Cancer Res. 2011, 17, 6118-6124. [CrossRef] [PubMed]

91. Spranger, S.; Spaapen, R.M.; Zha, Y.; Williams, J.; Meng, Y.; Ha, T.T.; Gajewski, T.F. Up-regulation of PD-L1, IDO, and $\mathrm{T}_{\text {regs }}$ in the melanoma tumor microenvironment is driven by CD8 ${ }^{+} \mathrm{T}$ cells. Sci. Transl. Med. 2013. [CrossRef] [PubMed]

92. Filipazzi, P.; Bürdek, M.; Villa, A.; Rivoltini, L.; Huber, V. Recent advances on the role of tumor exosomes in immunosuppression and disease progression. Semin. Cancer Biol. 2012, 22, 342-349. [CrossRef] [PubMed]

93. Ye, X.Z.; Yu, S.C.; Bian, X.W. Contribution of myeloid-derived suppressor cells to tumor-induced immune suppression, angiogenesis, invasion and metastasis. J. Genet. Genomics 2010, 37, 423-430. [CrossRef]

94. Yang, L.; DeBusk, L.M.; Fukuda, K.; Fingleton, B.; Green-Jarvis, B.; Shyr, Y.; Matrisian, L.M.; Carbone, D.P.; Lin, P.C. Expansion of myeloid immune suppressor $\mathrm{Gr}+\mathrm{CD} 11 \mathrm{~b}+$ cells in tumor-bearing host directly promotes tumor angiogenesis. Cancer Cell 2004, 6, 409-421. [CrossRef] [PubMed]

95. Du, R.; Lu, K.V.; Petritsch, C.; Liu, P.; Ganss, R.; Passegue, E.; Song, H.; Vandenberg, S.; Johnson, R.S.; Werb, Z; i et al. HIF1alpha induces the recruitment of bone marrow-derived vascular modulatory cells to regulate tumor angiogenesis and invasion. Cancer Cell 2008, 13, 206-220. [CrossRef] [PubMed]

96. Kujawski, M.; Kortylewski, M.; Lee, H.; Herrmann, A.; Kay, H.; Yu, H. Stat3 mediates myeloid cell-dependent tumor angiogenesis in mice. J. Clin. Invest. 2008, 118, 3367-3377. [CrossRef] [PubMed]

97. Friedlander, M.; Dorrell, M.I.; Ritter, M.R.; Marchetti, V.; Moreno, S.K.; El-Kalay, M.; Bird, A.C.; Banin, E.; Aguilar, E. Progenitor cells and retinal angiogenesis. Angiogenesis 2007, 10, 89-101. [CrossRef] [PubMed]

98. Hiratsuka, S.; Watanabe, A.; Aburatani, H.; Maru, Y. Tumour-mediated upregulation of chemoattractants and recruitment of myeloid cells predetermines lung metastasis. Nat. Cell Biol. 2006, 8, 1369-1375. [CrossRef] [PubMed]

99. DeNardo, D.G.; Barreto, J.B.; Andreu, P.; Vasquez, L.; Tawfik, D.; Kolhatkar, N.; Coussens, L.M. CD4(+) T cells regulate pulmonary metastasis of mammary carcinomas by enhancing protumor properties of macrophages. Cancer Cell 2009, 16, 91-102. [CrossRef] [PubMed]

100. Huysentruyt, L.C.; Mukherjee, P.; Banerjee, D.; Shelton, L.M.; Seyfried, T.N. Metastatic cancer cells with macrophage properties: Evidence from a new murine tumor model. Int. J. Cancer 2008, 123, 73-84. [CrossRef] [PubMed]

101. Pawelek, J.M.; Chakraborty, A.K. Fusion of tumour cells with bone marrow-derived cells: A unifying explanation for metastasis. Nat. Rev. Cancer 2008, 8, 377-386. [CrossRef] [PubMed] 
102. Clark, C.E.; Hingorani, S.R.; Mick, R.; Combs, C.; Tuveson, D.A.; Vonderheide, R.H. Dynamics of the immune reaction to pancreatic cancer from inception to invasion. Cancer Res. 2007, 67, 9518-9527. [CrossRef] [PubMed]

103. Sinha, P.; Okoro, C.; Foell, D.; Freeze, H.H.; Ostrand-Rosenberg, S.; Srikrishna, G. Proinflammatory S100 proteins regulate the accumulation of myeloid-derived suppressor cells. J. Immunol. 2008, 181, 4666-4675. [CrossRef] [PubMed]

104. Hermani, A.; De Servi, B.; Medunjanin, S.; Tessier, P.A.; Mayer, D. S100A8 and S100A9 activate MAP kinase and NF-kappaB signaling pathways and trigger translocation of RAGE in human prostate cancer cells. Exp. Cell Res. 2006, 312, 184-197. [CrossRef] [PubMed]

105. Kao, J.; Ko, E.C.; Eisenstein, S.; Sikora, A.G.; Fu, S.; Chen, S.H. Targeting immune suppressing myeloid-derived suppressor cells in oncology. Crit. Rev. Oncol. Hematol. 2011, 77, 12-19. [CrossRef] [PubMed]

106. Ko, J.S.; Rayman, P.; Ireland, J.; Swaidani, S.; Li, G.; Bunting, K.D.; Rini, B.; Finke, J.H.; Cohen, P.A. Direct and differential suppression of myeloid-derived suppressor cell subsets by sunitinib is compartmentally constrained. Cancer Res. 2010, 70, 3526-3536. [CrossRef] [PubMed]

107. Ko, J.S.; Zea, A.H.; Rini, B.I.; Ireland, J.L.; Elson, P.; Cohen, P.; Golshayan, A.; Rayman, P.A.; Wood, L.; Garcia, J.; et al. Sunitinib mediates reversal of myeloid-derived suppressor cell accumulation in renal cell carcinoma patients. Clin. Cancer Res. 2009, 15, 2148-2157. [CrossRef] [PubMed]

108. Priceman, S.J.; Sung, J.L.; Shaposhnik, Z.; Burton, J.B.; Torres-Collado, A.X.; Moughon, D.L.; Johnson, M.; Lusis, A.J.; Cohen, D.A.; Iruela-Arispe, M.L.; et al. Targeting distinct tumor-infiltrating myeloid cells by inhibiting CSF-1 receptor: Combating tumor evasion of antiangiogenic therapy. Blood 2010, 115, 1461-1471. [CrossRef] [PubMed]

109. Xu, J.; Escamilla, J.; Mok, S.; David, J.; Priceman, S.; West, B.; Bollag, G.; McBride, W.; Wu, L. CSF1R signaling blockade stanches tumor-infiltrating myeloid cells and improves the efficacy of radiotherapy in prostate cancer. Cancer Res. 2013, 73, 2782-2794. [CrossRef] [PubMed]

110. Stiff, A.; Trikha, P.; Wesolowski, R.; Kendra, K.; Hsu, V.; Uppati, S.; McMichael, E.; Duggan, M.; Campbell, A.; Keller, K.; et al. Myeloid-Derived Suppressor Cells Express Bruton's Tyrosine Kinase and Can Be Depleted in Tumor-Bearing Hosts by Ibrutinib Treatment. Cancer Res. 2016, 76, 2125-2136. [CrossRef] [PubMed]

111. Nefedova, Y.; Fishman, M.; Sherman, S.; Wang, X.; Beg, A.A.; Gabrilovich, D.I. Mechanism of all-trans retinoic acid effect on tumor-associated myeloid-derived suppressor cells. Cancer Res. 2007, 67, 11021-11028. [CrossRef] [PubMed]

112. Ugel, S.; Delpozzo, F.; Desantis, G.; Papalini, F.; Simonato, F.; Sonda, N.; Zilio, S.; Bronte, V. Therapeutic targeting of myeloid-derived suppressor cells. Curr. Opin. Pharmacol. 2009, 9, 470-481. [CrossRef] [PubMed]

113. Mirza, N.; Fishman, M.; Fricke, I.; Dunn, M.; Neuger, A.M.; Frost, T.J.; Lush, R.M.; Antonia, S.; Gabrilovich, D.I. All-trans-retinoic acid improves differentiation of myeloid cells and immune response in cancer patients. Cancer Res. 2006, 66, 9299-9307. [CrossRef] [PubMed]

114. Michels, T.; Shurin, G.V.; Naiditch, H.; Sevko, A.; Umansky, V.; Shurin, M.R. Paclitaxel promotes differentiation of myeloid-derived suppressor cells into dendritic cells in vitro in a TLR4-independent manner. J. Immunotoxicol. 2012, 9, 292-300. [CrossRef] [PubMed]

115. Sevko, A.; Michels, T.; Vrohlings, M.; Umansky, L.; Beckhove, P.; Kato, M.; Shurin, G.V.; Shurin, M.R.; Umansky, V. Antitumor effect of paclitaxel is mediated by inhibition of myeloid-derived suppressor cells and chronic inflammation in the spontaneous melanoma model. J. Immunol. 2013, 190, 2464-2471. [CrossRef] [PubMed]

116. Friedman, A. Transcriptional control of granulocyte and monocyte development. Oncogene 2007, 26, 6816-6828. [CrossRef] [PubMed]

117. Song, X.; Ye, D.; Liu, B.; Cui, J.; Zhao, X.; Yi, L.; Liang, J.; Song, J.; Zhang, Z.; Zhao, Q. Combination of all-trans retinoic acid and a human papillomavirus therapeutic vaccine suppresses the number and function of immature myeloid cells and enhances antitumor immunity. Cancer Sci. 2009, 100, 334-340. [CrossRef] [PubMed]

118. Iclozan, C.; Antonia, S.; Chiappori, A.; Chen, D.T.; Gabrilovich, D. Therapeutic regulation of myeloid-derived suppressor cells and immune response to cancer vaccine in patients with extensive stage small cell lung cancer. Cancer Immunol. Immunother. 2013, 62, 909-918. [CrossRef] [PubMed] 
119. Sevko, A.; Kremer, V.; Falk, C.; Umansky, L.; Shurin, M.R.; Shurin, G.V.; Umansky, V. Application of paclitaxel in low non-cytotoxic doses supports vaccination with melanoma antigens in normal mice. J. Immunotoxicol. 2012, 9, 275-281. [CrossRef] [PubMed]

120. Suzuki, E.; Kapoor, V.; Jassar, A.S.; Kaiser, L.R.; Albelda, S.M. Gemcitabine selectively eliminates splenic Gr-1+/CD11b+ myeloid suppressor cells in tumor-bearing animals and enhances antitumor immune activity. Clin. Cancer Res. 2005, 11, 6713-6721. [CrossRef] [PubMed]

121. Vincent, J.; Mignot, G.; Chalmin, F.; Ladoire, S.; Bruchard, M.; Chevriaux, A.; Martin, F.; Apetoh, L.; Rébé, C.; Ghiringhelli, F. 5-Fluorouracil selectively kills tumor-associated myeloid-derived suppressor cells resulting in enhanced T cell-dependent antitumor immunity. Cancer Res. 2010, 70, 3052-3061. [CrossRef] [PubMed]

122. Zollo, M.; Di Dato, V.; Spano, D.; De Martino, D.; Liguori, L.; Marino, N.; Vastolo, V.; Navas, L.; Garrone, B.; Mangano, G.; et al. Targeting monocyte chemotactic protein-1 synthesis with bindarit induces tumor regression in prostate and breast cancer animal models. Clin. Exp. Metast. 2012, 29, 585-601. [CrossRef] [PubMed]

123. Draghiciu, O.; Lubbers, J.; Nijman, H.W.; Daemen, T. Myeloid derived suppressor cells—An overview of combat strategies to increase immunotherapy efficacy. Oncoimmunology 2015. [CrossRef] [PubMed]

124. Umansky, V.; Schirrmacher, V. Nitric oxide-induced apoptosis in tumor cells. Adv. Cancer Res. 2001, 82, 107-131. [PubMed]

125. Capuano, G.; Rigamonti, N.; Grioni, M.; Freschi, M.; Bellone, M. Modulators of arginine metabolism support cancer immunosurveillance. BMC Immunol. 2009. [CrossRef] [PubMed]

126. Noonan, K.A.; Ghosh, N.; Rudraraju, L.; Bui, M.; Borrello, I. Targeting immune suppression with PDE5 inhibition in end-stage multiple myeloma. Cancer Immunol. Res. 2014, 2, 725-731. [CrossRef] [PubMed]

127. Califano, J.A.; Khan, Z.; Noonan, K.A.; Rudraraju, L.; Zhang, Z.; Wang, H.; Goodman, S.; Gourin, C.G.; Ha, P.K.; Fakhry, C.; et al. Tadalafil augments tumor specific immunity in patients with head and neck squamous cell carcinoma. Clin. Cancer Res. 2015, 21, 30-38. [CrossRef] [PubMed]

128. Weed, D.T.; Vella, J.L.; Reis, I.M.; De la Fuente, A.C.; Gomez, C.; Sargi, Z.; Nazarian, R.; Califano, J.; Borrello, I.; Serafini, P. Tadalafil reduces myeloid-derived suppressor cells and regulatory $\mathrm{T}$ cells and promotes tumor immunity in patients with head and neck squamous cell carcinoma. Clin. Cancer Res. 2015, 21, 39-48. [CrossRef] [PubMed]

129. De Santo, C.; Serafini, P.; Marigo, I.; Dolcetti, L.; Bolla, M.; Del Soldato, P.; Melani, C.; Guiducci, C.; Colombo, M.P.; Iezzi, M.; et al. Nitroaspirin corrects immune dysfunction in tumor-bearing hosts and promotes tumor eradication by cancer vaccination. Proc. Natl. Acad. Sci. USA 2005, 102, 4185-4190. [CrossRef] [PubMed]

130. Fujita, M.; Kohanbash, G.; Fellows-Mayle, W.; Hamilton, R.L.; Komohara, Y.; Decker, S.A.; Ohlfest, J.R.; Okada, H. COX-2 blockade suppresses gliomagenesis by inhibiting myeloid-derived suppressor cells. Cancer Res. 2011, 71, 2664-2674. [CrossRef] [PubMed]

131. Meyer, C.; Cagnon, L.; Costa-Nunes, C.M.; Baumgaertner, P.; Montandon, N.; Leyvraz, L.; Michielin, O.; Romano, E.; Speiser, D.E. Frequencies of circulating MDSC correlate with clinical outcome of melanoma patients treated with ipilimumab. Cancer Immunol. Immunother. 2014, 63, 247-257. [CrossRef] [PubMed]

132. Ozao-Choy, J.; Ma, G.; Kao, J.; Wang, G.X.; Meseck, M.; Sung, M.; Schwartz, M.; Divino, C.M.; Pan, P.Y.; Chen, S.H. The novel role of tyrosine kinase inhibitor in the reversal of immune suppression and modulation of tumor microenvironment for immune-based cancer therapies. Cancer Res. 2009, 69, 2514-2522. [CrossRef] [PubMed]

133. Bronte, V.; Zanovello, P. Regulation of immune responses by L-arginine metabolism. Nat. Rev. Immunol. 2005, 5, 641-654. [CrossRef] [PubMed]

134. Serafini, P.; Meckel, K.; Kelso, M.; Noonan, K.; Califano, J.; Koch, W.; Dolcetti, L.; Bronte, V.; Borrello, I. Phosphodiesterase- 5 inhibition augments endogenous antitumor immunity by reducing myeloid-derived suppressor cell function. J. Exp. Med. 2006, 203, 2691-2702. [CrossRef] [PubMed]

135. Gebhardt, C.; Sevko, A.; Jiang, H.; Lichtenberger, R.; Reith, M.; Tarnanidis, K.; Holland-Letz, T.; Umansky, L.; Beckhove, P.; Sucker, A.; et al. Myeloid Cells and Related Chronic Inflammatory Factors as Novel Predictive Markers in Melanoma Treatment with Ipilimumab. Clin. Cancer Res. 2015, 21, 5453-5459. [CrossRef] [PubMed] 
136. Martens, A.; Wistuba-Hamprecht, K.; Geukes Foppen, M.; Yuan, J.; Postow, M.A.; Wong, P.; Romano, E.; Khammari, A.; Dreno, B.; Capone, M.; et al. Baseline Peripheral Blood Biomarkers Associated with Clinical Outcome of Advanced Melanoma Patients Treated with Ipilimumab. Clin. Cancer Res. 2016, 22, 2908-2918. [CrossRef] [PubMed]

137. Sade-Feldman, M.; Kanterman, J.; Klieger, Y.; Ish-Shalom, E.; Mizrahi, O.; Saragovi, A.; Shtainberg, H.; Lotem, M.; Baniyash, M. Clinical significance of circulating CD33+CD11b+HLA-DR-myeloid cells in Stage-IV melanoma patients treated with ipilimumab. Clin. Cancer Res. 2016, 139, 1915-1926. [CrossRef] [PubMed]

(C) 2016 by the authors; licensee MDPI, Basel, Switzerland. This article is an open access article distributed under the terms and conditions of the Creative Commons Attribution (CC-BY) license (http:/ / creativecommons.org/licenses/by/4.0/). 